\title{
Research on the Development of China's Automotive Vocational Education under School-enterprise Cooperation Model
}

\author{
Huanxin Sun \\ Beijing Information Technology College \\ Beijing, China
}

\begin{abstract}
The research was based on the problems of current Chinese automotive vocational education under which schoolenterprise cooperation model. After detailed study of the background information and current situation of China's automotive vocational education, a series of related solutions were carried out, namely, the strategies from the perspective of legal system and society orientation. Some researches on the reform of China's automotive vocational education were also done in this paper.
\end{abstract}

Keywords-Automotive Vocational Education, Schoolenterprise Cooperation Model, automobile industry

\section{INTRODUCTION}

In recent years, with the rapid development of automobile industry, China's automotive vocational education has been further developed. However, the automotive vocational education is facing opportunities as well as challenges. China's automotive vocational education under school-enterprise cooperation have produced numerous practical professionals, but according to a current study, the relative separation still exists between schools and enterprises. Therefore, while strengthening the connotation construction, schools should pay more attention to the combination between students' theoretical learning and practice. Based on the completion of training objectives, the graduates could match fairly well with corporations, and schools and businesses share their common interests. Notwithstanding that automotive vocational education has its particular professional needs, the natural requirement of which the theory and practice go hand in hand, as well as the essential demand that students should achieve great integration with the enterprise, both will not change. Schoolenterprise cooperation achieves the organic combination between school educations which basically imparting knowledge in classroom and R\&D which directly obtain practical ability.

\section{THE SIGNIFICANCE OF SCHOOL AND ENTERPRISE} COOPERATION IN AUTOMOTIVE VOCATIONAL EDUCATION

With the current trend of automotive vocational education, the university-industry collaboration is the only choice; moreover, the school-enterprise cooperation is an important way to achieve the goal of university-industry collaboration. Thus, school-enterprise cooperation is the most important factor of the reform. Its significance is as follows:

\section{A. Achieve the substance of vocational education}

Although compared with Germany, USA, UK and Japan, the development of China's automotive vocational education is still relatively backwards, with the deepening of reform and opening up, as well as economic development; the vocational education was greatly pushed forward. Coproduction with teaching and the combination of working with learning advocated by school-enterprise cooperation is a necessary requirement of its occupational character, and also the concrete reflection of the principle which education should combine with productive labor on vocational education; it achieved a natural return to vocational education. Vocational education belongs to employment education, it cannot be successful merely by the strength of the school, and more efforts are needed from government's support. According to job requirements, education and training program should be tailor-made for students, so as to achieve the combination between workshops with classrooms, the combination between students and apprentices, the combination between teachers and master workers, the combination between theory and practice, the combination between works and production, as well as the combination between education and income generation.

\section{B. In line with the national employment-centered guiding ideology}

The principle of China's vocational education is for the purpose of good services and employment-oriented. It calls for the shift from research institutions positioning to applicative institution positioning. On one hand, schoolenterprise cooperation helps students obtain work experience in the actual production and achieves the requirements of enterprises for their employees; on the other hand, making both vocational colleges and students have the ability improved. This ability is not only reflected on the program of work, more importantly, it's reflected on the students' understanding of the work, and on the understanding of the corporate culture, as well as on the combination of theory 
and practice to achieve the value. Moreover, schoolenterprise cooperation builds a complete platform of employ ment information to help students, vocational schools and enterprises achieve good communication, and to achieve more efficient channel of employment, finally to save resources for the family, the country, and the society at the macro level.

\section{Change the traditional status of classroom-centered teaching}

Traditional education mainly concentrates on teaching in classroom, under this condition, teachers impart knowledge based on theory, this kind of education is not suitable for modern application-oriented vocational schools, the main reason behind that is because the traditional education method is apt to failed to make an effective combination between learning and using, which on the whole is a tremendous waste of resources for the country. Schoolenterprise cooperation succeeds to narrow the gap between the enterprises and the colleges, to achieve zero distance contact between theory and practice. School-enterprise cooperation constructed a teaching system that based on the need of employees and job competency. Whether on the part of discipline construction or on the part of training target, it makes the transition from the existing curriculum design in vocational education to professional competent building, and undermine the boundaries between theory and practice, emphasizing on the combination between learning environment and business environment, to make students easier added their value to corporations after graduation .

\section{BACKGROUND INFORMATION AND CURRENT SITUATION OF CHINA'S AUTOMOTIVE VOCATIONAL EDUCATION}

It has been a century since the invention of the automobile, thus its design and manufacturing technology is very mature today. With the deepening process of China's reform and opening up, foreign-made cars flooded into our country, therefore, China's car market has been growing prosperous. Under such circumstance, China's automobile manufacturing and repairing industry has enjoyed rapid development. However, according to the analysis of the current situation of China's automotive industry, our country is still under world-class level as regard to the current technology, to the quality of skillful workers, and to the reservation of talents. As we all know, since the world's energy crisis and environmental is sues increasingly emerges, more and more domestic research institutes and universities have committed to the research of new energy vehicle technology, which has brought not only huge opportunities but also challenges for China's automotive vocational education. In many foreign countries, the experts have explored the development of a new model of vocational education, for instance, the dual system of vocational education in Germany. As for Australia, under the framework of national training, it established the industry guidance system. The vocational education in British adopted a new model of cooperative education. The new educational model has promoted the vocational education continually. However, there are series of problems exists in China's automotive vocational education, what's worse, these is sues conflicting with each other and made them difficult to handle. On one hand, there is a large talent gap in auto industry; on the other hand, the graduates in the field always suffer undesired treatment such as low wage, uncertain future development and other is sues. This paper argues that the reasons accounting for this paradox are various, but mainly the declining quality of the students and current situation of China's automotive vocational education. Due to the fact that many students lack professional competence, careless working attitude, weaken in operational ability, poor ability to adjustment, lack of initiative in job and so on. These problems make the graduates failed to adapt themselves to the work environment when entering enterprises, not alone to create value for the business. Nevertheless, these problems cause the poor quality of students. In order to change the existing problems in automotive vocational education, this paper studies on the basis of the development of the Chinese automotive vocational education under which school-enterprise cooperation mode, trying to find the means to solve this problem, thus to achieve the teaching ideology of better service, employment-oriented, core skills, quality education.

\section{REFLECTIONS ON DEEPENING THE SCHOOL- ENTERPRISE COOPERATION IN CHINA'S AUTOMOTIVE VOCATIONAL EDUCATION}

The School-enterprise cooperation of automotive education achieved production-study-research collaboration; they are mutually element, motivation and mechanism. School-enterprise cooperation is an effective channel to make the automotive vocational education market-oriented and serve business, but the current school running thoughts and teaching ideologies of vocational schools make it difficult to achieve that. Therefore, we must accelerate the pace of deepening school-enterprise cooperation and establishing thoughts and ideas that in line with the development requirements of the enterprises, to earnestly build service chain linking schools and businesses.

\section{A. Change the leading role that school plays in school- enterprise cooperation, to establish cooperative relations of mutual assistance}

The school-enterprise cooperation can not simply be led by the school part; instead, the current status of the model should be fundamentally altered, in order to achieve the relationship of mutual trust and win-win. Firstly, systematically, we ought to establish the shared decisionmaking process between schools and enterprises, to unify the development of institute and school, to unify the planning of college and business. For example, to change the original single source of students, and to set up the selection mode of enterprise-oriented, so that realizes a combination between students and staff. Secondly, for the teaching staff construction, dual-qualified teachers are expected. The companies offer dual-qualified teachers for schools. Make efforts to establish a business decision based on dualqualified teaching system in the Ministry of Education 
assessment, rather than the blind introduction of highly educated but do not meet enterprise teaching requirements just for the purpose of education system assessment. Moreover, it needs to establish joint curriculum for enterprises and schools. Since cooperative educational institutions require that courses must meet the needs of enterprises, the curriculum plan must be done by businesses and schools through negotiation. It's not wise to simply pursue the interests of the school without taking the development of enterprises into consideration. We should make enterprises participate in the college curriculum, and college take part in the operation of enterprises. As long as they can insist on mutual cooperative relationship, it will be beneficial to both parties. As China continues to develop and advance the socialist market economy, as well as the marketoriented guiding ideology, both call for vocational schools actively understanding the needs of enterprises, and making training plan together to cultivate talents, and the companies will have to participate in the set of training objectives and curriculum designing, all of these are in accordance with the needs of the modern job market, but also meet the needs of our vocationaleducation reform.

\section{B. Get rid of the vocational education that consider educational background as precondition, to establish the vocational education that based on the foster of market skills}

China's education industry always takes educational background as its top priority. Such fact is a result of historical reasons and is also caused by the needs of future development. However, it does not mean that China's automobile vocational education should take educational background as premise. The vocational education in China has just started lately, if positioned as research institute. It would be hard to work well. The positioning as applicationoriented vocational education is now widely accepted. The so-called application-oriented professional education, in the essence, is to develop skillful talents catering for job requirements. Therefore, there are conflicts on the issue of whether skills-based education or academic education should be put in the first place. The modern vocational education should abandon the original opinion that academic education goes first; instead, it ought to set the idea of skills first and then the degree, highlighting the distinctive characteristics of application-oriented education. To establish the skills-based school-running system, training students in line with job requirements rather than relatively applied talents under the academic training system. Even under the condition that get rid of qualification oriented education system, the current three-year or four-year training regulation should be replaced by certain limitation of time that in compliance with the market demand.

\section{Standardize the assessment criteria of vocational education skills certificate and improve the skills of gold}

In spite of the fact that the assessment of China's automotive vocational skills certificate has made gratifying achievements, there are many problems emerge, such as unsuitable skill certificates, skills certificate can not keep pace with the times, assessment requirements have become formulaic. The main problems of the current skills certificate consist in such facts as lacking accordance with times, lacking enterprises' participation in the set of standard, lacking acceptance of its status and role, as well as the fact that its frontier is subjected to the restrictions of China's vocational education system. In the modern job market, we can easily find out that if an employee has a certificate of TEM 8, but not have qualifications, his social values will also be admitted. It shows the urgency for the vocational education to get rid of qualifications. After a break with the training model of academic education, to establish the skills certificate that suit for vocational education, standardize assessment methods, setting standards for scientific assessment, promoting vocational skills certificate service system. Therefore make it not only in line with business requirements but also the social recognition value, such as automotive engineer and senior automotive engineer.

\section{Establish and deepen the cooperative education, and promote the sound development of school-enterprise cooperation}

The university-industry cooperation becomes an inevitable trend of future development, which requires the schools and businesses to reach some consensus, and share common goals for development. For competent schools, businesses and schools jointly established the research studio, selecting talented students and dual-qualified teachers as studio staff. They specialize in a number of projects appropriate for enterprise and social's development and design, so that not only help students get to know the working process, but also lay a good foundation for their careers. And since students need go though selection before qualified to stay in the studio, it is conducive to mobilize the initiative of students, and can bring a certain reference value for society.

\section{OUTLOOK OF SCHOOL-ENTERPRISE COOPERATION MODEL OF AUTOMOTIVE VOCATIONAL EDUCATION}

China's auto industry is undergoing a strategic transitional phase; therefore, large amounts of talents who meet the demands of the country and cooperation are required. School-enterprise cooperation, while relying on the business is an ideal model for automotive vocational education. School-enterprise cooperation in running schools has a unique advantage. On one hand, the new model that schools and businesses docking each other will bring new opportunities for the development of the school and also improve the status of schools, as a result, the quality of schools will be affirmed by enterprises, and the schools will gain popularity among students, as well as approval by parents; on the other hand, school-business cooperation is not a simple combination, it needs to be deepened effectively in all aspects. That calls for joint efforts from schools, businesses and the entire community. I firmly believe that the school-enterprise cooperation boasts promising future. 


\section{REFERENCES}

[1] Zhang Xiaoping. Analysis automotive vocational education schoolenterprise cooperation model [J]. Education and Vocational,2012, 33:38-40.

[2] Majun. Explore new modes of school-enterprise cooperation - 2012 annual meeting of the National Automobile Xie Ying Vocational Education $[\mathrm{J}]$ car repair and maintenance, 2012, 12:34+36 +38.

[3] Mao jun. Based on the development of Chinese automobile vocational education school-enterprise cooperation mode. Chinese school education [J], 2013, 21:136-137.

[4] Daizuliang. To construct on behalf of the progenitor good vocational and technical education system and its countermeasures [D]. Kunming University, 2002.

[5] Li qi. Study of rural vocational education school-enterprise cooperation mode [D]. Northeast Normal University, 2008.
[6] Zhangqian. Vocational schools run school-enterprise cooperation mechanism of [D]. East China Normal University, 2012.

[7] Pan Xiaoyan. Yangtze private colleges sponsoring school-enterprise cooperation model study [D]. East China University of Political Science and Law, 2013.

[8] Zhang Zhao. Henan Vocational Education Group in the development of the current problems and countermeasures [D]. Henan University, 2013.

[9] Zhang Sainan. Moral Education to work in the school-enterprise cooperation background research [D]. Hunan University, 2013. 